\title{
Becoming (p)art: Fostering socially engaged leadership for preservice art teachers through service-learning
}

\section{Merna Meyer}

COMBER, Faculty of Education, Potchefstroom, North-West University, South Africa merna.meyer@nwu.ac.za https://orcid.org/0000-0002-8038-6024

\section{Lesley Wood}

COMBER, Faculty of Education, Potchefstroom, North-West University, South Africa

Lesley.Wood@nwu.ac.za

https://orcid.org/0000-0002-9139-1507

(Received: 14 February 2019; accepted: 24 June 2019)

\section{Abstract}

To provide a more socially engaged learning environment for preservice teachers in art education, the first author engaged them in a critical service-learning project. In five cycles of action and reflection on the engagement process, she generated evidence about student learning through observations, reflective notes, and visual images to support her self-study on how she could influence preservice art teachers to become educational leaders by adopting socially engaged practices. Qualitative analysis revealed that, after completing the module, students considered including socially engaged art in their teaching and showed qualities of becoming critical, accountable, and transformational leaders - and better prepared for teaching inclusively and in diverse contexts. The model developed from the first author's learning serves as a praxis-orientated instrument to guide pedagogies to increase social responsiveness amongst preservice art teachers to make their future practice more contextually relevant.

Keywords: action research, action leadership, critical service-learning, participatory artist, researcher teacher (p)art, professional development, socially engaged art

\section{Introduction}

In this self-reflective inquiry of my practices in art education, I (the first author) address my concern about teaching art in isolation from the social realities of learners. My aim was to improve my understanding of how I could introduce students to socially engaged art practices to make their teaching more socially responsive. By socially engaged art (SEA), I mean education programmes that promote an "awareness of social and political contexts of education and the development of critical consciousness about issues such as race, class, 
gender, culture, language, and educational equity" (Howard \& Aleman, 2008, p. 158). In post-apartheid South Africa, education policies mandate that higher education teaching programmes should incorporate situational elements that assist teachers to develop competencies to deal with diversity and transformation, and to work "flexibly and effectively in a variety of contexts" (Department of Higher Education and Training, 2015, p. 9). Context is particularly relevant in this country where the impact of apartheid is still tangible, and considerable socioeconomic divides still exist.

Although there is increased recognition that developing teacher capacity for inclusive and socially engaged practices is critically important, there remains little guidance on the pedagogies and curriculum structures that promote these capacities in the professional development of teachers (DeLuca, DeLagran, Feurguson, \& Ho, 2011). I agree with Wood (2012) that allowing students to exit campus with little exposure to participatory pedagogies in diverse and inclusive learning environments contributes to a fragmentary knowledge of the contexts in which learners live, and leads to a lack of empathic understanding of diversity and social inequalities.

My intent is to prepare socially responsible art educators who value the principles of social justice, and understand the importance of integrating them into their future teaching practice. I want students to understand art as a creative, expressive, and beneficial tool for learning that should be accessible to all. Also, art can connect different subjects to relevant issues in transdisciplinary engagements, raise critical consciousness, and foster a sense of social responsibility between participants from diverse backgrounds, enhancing empathic understanding and improving intercultural relationships (Meyer \& Wood, 2017). Thus, applying art in multidimensional ways, and developing art teachers as leaders, can raise the status of art as a subject in schools - in contrast to the current marginalised position it tends to occupy. In art education, opportunities to educate preservice teachers to be adaptable and open to different contexts, to adopt inclusive stances towards cultures, languages, and ways of living, are under explored (Wood \& Meyer, 2016).

In this article, I thus pose the question: "How can I influence preservice art education students to become leaders in their learning environments by adopting more socially engaged practices?" I first provide a detailed account of SEA, a socially engaged art approach to active learning and leadership. Next, I explain how critical service-learning provides a vehicle for enabling socially engaged art. I then elucidate how I generated evidence to support my claims of having learnt how to develop preservice art teachers' capacity for taking leadership through socially engaged, inclusive practices. I conclude by reflecting on the significance of such practices for preservice art teacher programmes.

\section{Socially engaged art approach to active learning and leadership}

Socially engaged art is a transpedagogic educational theory that combines knowledge from a combination of disciplines - in this study, from teacher education, drama, environmental 
studies, and the real-life contributions of artists' work. It has a strong emancipatory agenda with its roots in the late 1960s feminist education theories (Helguera, 2011), and is aimed at "liberating art practices from strict art historical interpretations and contexts" (Helguera, 2011, p. ix). SEA also aligns with participatory educational practices-engagement with audiences, inquiry-based methods, collaborative dialogues, and hands-on activities, with social interaction occupying the central focus of any activity. SEA expands the depth of social relationships by creating a social conscience about a situation and then instigating a collaborative action or experience instead of "[walking] blindly into a situation ... with little care about the outcomes" (Helguera, 2011, p. 8). It involves learning how to moderate a conversation, negotiate interests in a group, and assess the complexities of a given social situation. SEA activities promote artistic liberty, but with a strong social agenda. Art teachers need to "become more aware of the context and thus allow [themselves] to better influence and orchestrate desired outcomes" (Helguera, 2011, p. xv).

\section{Critical service-learning as a vehicle for socially engaged art practices}

Critical service-learning (CSL; Rice \& Pollack, 2000) serves as a vehicle for "connecting students and institutions to their communities and the larger social good, while at the same time instilling in students the values of community and social responsibility" (Neururer \& Rhoads, 1998, p. 321). It has a social justice intent (Mitchell, 2008) to transform "structural inequalities" (Rosenberger, 2000, p. 29) through complex thinking and reasoning skills, instead of merely providing service to the community (Mitchell, 2008). Although literature reveals different perspectives about the most distinguishing elements of critical servicelearning (Porfilio \& Hickman, 2011), I agree with Doerr (2011) that an understanding of three components are central to critical service-learning: power, privilege, and the identification of the root causes of social issues. As a teacher educator in South Africa, I need to provide opportunities for students to understand the power their privilege endows, and how such privilege is a result of years of sociohistorical oppression of the majority of the population. In this case, I guided students through five sessions and eight activity cycles of action learning to help them reflect on the value of engaging in art activities with young people from a children's home. At the same time, I reexamined my practices and asked questions about my role, thinking critically about my position and presence in guiding students through their learning experience. I view critical service-learning as a progressive pedagogy and instrument to encourage students to see themselves as agents of social change, and to use the experience of service to address and respond to injustices in their immediate communities.

To expose students to effective leadership, "both action and learning need to be ignited" (Zuber-Skerritt, 2011, p. 203). Leadership attributes that are developed by CSL include selfknowledge, knowledge about the needs of others, and emotional intelligence. I adopted the role of a facilitator who guides rather than directs, focusing on developing students' capacity, knowledge, skills, attitude, and democratic values. My "other-centred approach" (Zuber- 
Skerritt, 2011, p. 231) meant that I set myself on a path where I wanted to enrich students' lives with vision, passion, hope and empower them for their future careers.

\section{The service-learning project}

I developed the theme, "Living My Leadership in a Diverse and Healthy Environment," with the pedagogical intention of connecting students' learning experiences of leadership to a broader discourse on social responsibility and environmental issues. Students and learners were exposed to out-of-class learning sites to address green issues through various art forms, and to raise their awareness about global environmental awareness. The project involved 26 final year students (21-22 years, mostly women and Afrikaans-speaking, together with a few white English and black Sotho-Tswana students) teaching children from a local children's home. I chose this context because it would allow students to learn that not all people lead lives as privileged as their own. They met with each other on the university premises once a week in the afternoons for two hours over five sessions during the first semester.

The 15 children were of mixed race, boys and girls between 14 and 16 years of age, spoke mostly Afrikaans but understood both Afrikaans and English. We decided to meet at the university because it was convenient for the students who had to fit a busy academic programme into a six-week timeframe. The children's home management were keen to involve the children with skills-based activities, and offered transportation of the children to the university campus. The first session (relationship building) was held at the university's botanical gardens, the second (vision planning and design) and third (skills application) sessions, in the vicinity of the arts and crafts studio and, finally, a small-scale exhibition was held at the children's home premises. The final reflective session for the students was conducted in the classroom (see Table 1). 
Table 1: Participatory strategies used during a socially engaged art project

\begin{tabular}{|c|c|c|c|c|}
\hline & DESCRIPTION OF PARTICIPATORY STRATEGIES & PURPOSE AND AIM & $\begin{array}{l}\text { DATA GENERATION TECHNIQUES AND } \\
\text { DOCUMENTATION }\end{array}$ & $\begin{array}{l}\text { TIME } \\
\text { (HOURS) }\end{array}$ \\
\hline \multicolumn{5}{|c|}{ Session 1: RELATIONSHIP BUILDING } \\
\hline & $\begin{array}{l}\text { Introduction and orientation } \\
\text { Introduction of preservice art students and } \\
\text { children to one another } \\
\text { Establish trust and common interests } \\
\text { Discuss what to expect from the green theme } \\
\text { project }\end{array}$ & $\begin{array}{l}\text { Build trust and site orientation: introduce children to } \\
\text { environmental issues }\end{array}$ & Informal group discussion & \\
\hline $\begin{array}{l}\text { Activity } 1 \\
\text { (conducted by } \\
\text { students with } \\
\text { children) }\end{array}$ & $\begin{array}{l}\text { Ice breaker: Walk-and-talk activity } \\
\text { Discussions, guiding and sharing knowledge } \\
\text { about the area } \\
\text { Participants establish perceptions of each } \\
\text { other and the site }\end{array}$ & $\begin{array}{l}\text { Relational skills development: emphatic/sensitising exercises } \\
\text { Students guide children through a process of discovery and } \\
\text { sensory awareness of surroundings } \\
\text { What do they see, feel, smell, touch and think? }\end{array}$ & $\begin{array}{l}\text { Informal conversations } \\
\text { Participatory group discussions } \\
\text { Observations and sensory explorations }\end{array}$ & 2 \\
\hline \multirow[t]{2}{*}{$\begin{array}{l}\text { Activity } 2 \\
\text { (conducted by } \\
\text { students with } \\
\text { children) }\end{array}$} & $\begin{array}{l}\text { Playing fun games: Pretend to be a touristguide } \\
\text { and talk about environmental issues } \\
\text { Imaginary games: Pretend to be a tree } \\
\text { Throwing a ball and convey something } \\
\text { special/funny about themselves } \\
\text { Team-building game: Reflexivity }\end{array}$ & $\begin{array}{l}\text { Creating a make-believe world, detail context, recognising } \\
\text { issues related to the environment } \\
\text { Projecting own symbolising personal characteristic } \\
\text { To become more intuitive and respond to requests, develop } \\
\text { inter-personal relationships, sharing likes and dislikes } \\
\text { Reflexive gestures and interconnectedness }\end{array}$ & $\begin{array}{l}\text { Informal group discussions } \\
\text { Narrative reporting } \\
\text { Interactions } \\
\text { Observations } \\
\text { Miming and frozen gestures }\end{array}$ & \\
\hline & $\begin{array}{l}\text { Art-based exercises: } \\
\text { Making cut-outs and collages } \\
\text { Secret jar with personal characteristics } \\
\text { Splatter paint, prints and rubbings } \\
\text { Building from scratch with mixed media } \\
\text { and 3-D materials }\end{array}$ & $\begin{array}{l}\text { Mapping the problem/issues/need: To find out how } \\
\text { participants experience the learning environment, talk about } \\
\text { real-life issues and social concerns. Start to think about } \\
\text { challenges and how they can be solved, e.g., how can } \\
\text { garbage be converted into something beautiful? } \\
\text { Discovery of self-becoming untangled } \\
\text { Experiment with media and techniques: freedom of } \\
\text { expression } \\
\text { How is the living environment affected by social ills, how } \\
\text { can personal messages of hope be encapsulated in nature? }\end{array}$ & $\begin{array}{l}\text { Art-based items and art works } \\
\text { Collages, prints and recycled material } \\
\text { Student reflections on relational skills, } \\
\text { building trust, and sharing awareness }\end{array}$ & \\
\hline
\end{tabular}




\section{Session 2: VISION-BUILDING, PLANNING, AND INTERVENTION STRATEGIES}

Activity 3

(conducted by

students with

children)

\section{Activity 4 \\ (conducted by \\ students with \\ children}

(conducted by

students with

children

\section{Vision building}

Interactive vision building activity

Clarification of themes and needs analysis:

how do they see the issue being resolved?

Agendas and aims of project are discussed-

challenges, expectations and possibilities

mentioned

Groups explore how they will tackle the issues/problem; identify types of material, including recyclable resources; how will they create and maintain the work of art/artefact?

\section{Planning and designing}

Interactive visual/conceptual working process Own ideas/planning combined with visual designs of the children

Discuss and analyse different plans/designs, as well as materials to be used

Divide groups into different workstations

Rotate interactive engagement

Cooperate in finding solutions and a mutual platform to start project

\section{Intervention strategy}

Enhance ideas and consider other possibilities Use campus facilities to show different YouTube videos about land art, environmental art and sustainable projects

Revisit previous community-engaged projects with the upcycling theme

Demonstrate certain skills and functional uses of tools, e.g., spray-painting, cutting-knives

\section{Critical skills development}

Determine commonalities of thought—which factors can facilitate or hinder the process of creating an artwork/artefact?

Do participants have common goals and similar visions? How would they address the issue?

Discuss, reflect and compromise to reach mutually agreed upon decisions

\section{Organising and team work skills development}

Establish a working relationship

Identify own strengths-expectations regarding one

another's contribution, knowledge sharing, critical thinking Envisage working relationship (divide tasks)

Negotiate process and positions, working relation

Planning regarding types of materials to be used

\section{Exploring other possibilities in the real world-} professional skills development

Establish deeper understanding of real-world applications and own contribution to the final project

Present and share ideas

Accommodate complexity and extend knowledge baseinvestigating multi-media and transdisciplinary work

environments
Informal group discussions

Mind maps

Recycled material

Informal group discussion

Students and youths' collaborative designs

Interactive discussions

Research interventions (photographs,

pictures, YouTube aids)

Artefacts and artwork 


\begin{tabular}{|c|c|c|c|c|}
\hline \multicolumn{5}{|c|}{ Session 3: SKILLS APPLICATION STRATEGY } \\
\hline $\begin{array}{l}\text { Activity } 6 \\
\text { (conducted by } \\
\text { students with } \\
\text { children) }\end{array}$ & $\begin{array}{l}\text { Skills application process } \\
\text { Interactive teamwork and art-based skills } \\
\text { application activity } \\
\text { Painting, making, assembling, upcycling of } \\
\text { available resources, planting of floating } \\
\text { planters } \\
\text { Refinement and adding finishing touches }\end{array}$ & $\begin{array}{l}\text { Art-based skills in a collaborative working relationship } \\
\text { Work collaboratively on a product, task oriented: who is } \\
\text { doing what? } \\
\text { Individual and group work-rotating between different } \\
\text { materials and tool use } \\
\text { Complete different tasks in a dialogical manner }\end{array}$ & $\begin{array}{l}\text { Interactive individual and group participation } \\
\text { activities } \\
\text { Poster/artefact completion by using available } \\
\text { resources }\end{array}$ & 2 \\
\hline \multicolumn{5}{|c|}{ Session 4: EXHIBITION AND CELEBRATION STRATEGY } \\
\hline $\begin{array}{l}\text { Activity } 7 \\
\text { (organised by } \\
\text { lecturer; } \\
\text { participation of } \\
\text { students and } \\
\text { children) }\end{array}$ & $\begin{array}{l}\text { Exhibition and celebration event } \\
\text { Students and children exhibit their completed } \\
\text { work together } \\
\text { All stakeholders, e.g., managers, house- } \\
\text { matrons, lecturers, and participants gather at } \\
\text { the premises (the children's home) } \\
\text { Students and children present a gallery walk } \\
\text { activity and explain the social issues, meaning } \\
\text { of their work and their learning experience } \\
\text { during the CSL engagement process }\end{array}$ & $\begin{array}{l}\text { Showcasing socially engaged art projects and } \\
\text { transformed practices for public display } \\
\text { Learn to display own work and appreciate others' works } \\
\text { Learn more about other viewpoints and methods of } \\
\text { expressing social, contextual and environmental issues } \\
\text { Finalising their work }\end{array}$ & $\begin{array}{l}\text { Interactive explanations } \\
\text { Group work } \\
\text { Performance measurement } \\
\text { Exhibition }\end{array}$ & 2 \\
\hline \multicolumn{5}{|c|}{ Session 5: REFLECTION ON LEARNING } \\
\hline $\begin{array}{l}\text { Activity } 8 \\
\text { Living my } \\
\text { leadership } \\
\text { (explained by } \\
\text { lecturer; } \\
\text { students } \\
\text { complete } \\
\text { posters) }\end{array}$ & $\begin{array}{l}\text { Students reflect on all four sessions } \\
\text { Students design an academic poster to } \\
\text { showcase leadership and professional } \\
\text { development during CSL process }\end{array}$ & $\begin{array}{l}\text { Reflecting on learning process and capturing CSL } \\
\text { process in academic poster } \\
\text { Students reflect on the following: } \\
\text { What did they learn? } \\
\text { How did it benefit them? } \\
\text { Vision revisited? } \\
\text { Suggestions? } \\
\text { Embodied learning captured in leadership poster }\end{array}$ & $\begin{array}{l}\text { Reflective notes on all five phases } \\
\text { Poster design }\end{array}$ & 10 \\
\hline
\end{tabular}




\section{Method}

I generated data from the students' assignments, which included photos, artwork, and reflections collected after each session with the children. I thematically analysed (Braun \& Clarke, 2006) their reflections after each engagement. I then weighed the emerging themes against my concerns and pertinent research question (Saldaňa, 2016) to inform my analysis of the data (Ary, Jacobs, Sorensen, \& Walker, 2014). I validated my findings through the lens of SEA theory, and the relational, critical, collaborative, and transformative intent of critical service-learning (Frith \& Gleeson, 2004) and triangulated the data during the five sessions using various data generation activities and methods (Ellingson, 2009). The research process was transparent and complied with the university's ethics stipulations.

In the next section, I provide evidence of how my practice influenced students to become socially engaged art practitioners. To protect the students' identities, I denote codes to their names according to the age group they are training to teach, for example, senior intermediate phase (SI) and further education and training phase art students (SF).

\section{Discussion of findings}

The CSL engagement project created opportunities for action learning. Over four sessions, students became aware of their positional roles and their potential impact on children's lives.

Theme 1: Students learnt relational skills, and understood the importance of teaching with sensitivity

The students met the children for the first time at the university botanical gardens with the aim of establishing a trusting relationship. I suggested the groups start with a walk-and-talk exercise (The Long Walk, 2013) as an icebreaker to orientate them to their new surroundings, and to create spatial and personal awareness of a natural learning environment. This exercise enabled the students to notice the children's "shy and inhibited feelings" (SI_4), and so they took action to encourage them to open up. One student remarked:

They loved walking in nature and talking about the things they saw. They were very interested about the facts that I had to say and the new knowledge that came with it. They were a bit shy at first but as we walked and chatted, they came out of their shell and started asking questions and even answering them among themselves when they could. (SF_7)

I found the first relationship-building activity to be a good space to negotiate relations, and to promote communication and trust between the groups. SEA theory holds that "conversation is regarded as the centre of sociality, of collective understanding and organization" (Helguera, 2011, p. 40). Organised talks allow people to "engage with others, create community, learn together or simply share experiences without going any further" (Helguera, 2011, p. 41). Students learned that relationship building is essential because "team members are likely to experience all sorts of problems that can arise from competition, envy, shyness, 
denial, dominance by some and silence by others, and other personal qualities that can fuel tensions" (Zuber-Skerritt, 2013, p. 34). This open-air activity prepared the groups for the next level of their relationship-building process, which was more interactive, when I introduced multi-modal activities such as fun team-building and art-based exercises.

The arts-based activities resulted in various interactions. One of the groups encouraged spontaneous exchanges to create sensory awareness of their learning environment, by "looking [at the crabs in the pond], listening [to the birds], touching [the plants] and smelling [different flowers]" (SF_10). Other groups planned creative art-based lesson activities around art techniques such as printing (of leaves, creating butterflies; SF_18; see Figure 1), collage (cut-outs of children's favourite things; SF_11), making assemblages (pick up own organic and found materials; SI_20) and puzzle-building (mason jars filled with objects that the youth identified with most; SF_17). One group used well-known game-play activities such as a spontaneous reflex game known as "ninja-ha" (SI_20), "fun-facts quizzes about nature" (SF_4), and metaphoric projections of nature (tree that symbolises the children best; SI_10) to get to know each other. Drawing from Augusto Boal's (2000) ideas of the invisible theatre imitating reality, one group acted as tour guides reciting anecdotes to inform the rest of the group about their surroundings (SI_21). Students considered the activities to be valuable learning opportunities "to work together and get to know each other better" (SF_6), and to "build a relationship with the children through art and to grow respect for the environment" (SF_18). They became comfortable teaching in unfamiliar open spaces: "Teaching out of class becomes a truly free and creative exercise as opposed to classroom teaching methods such as the "redrawing of pictures" (SF_12).

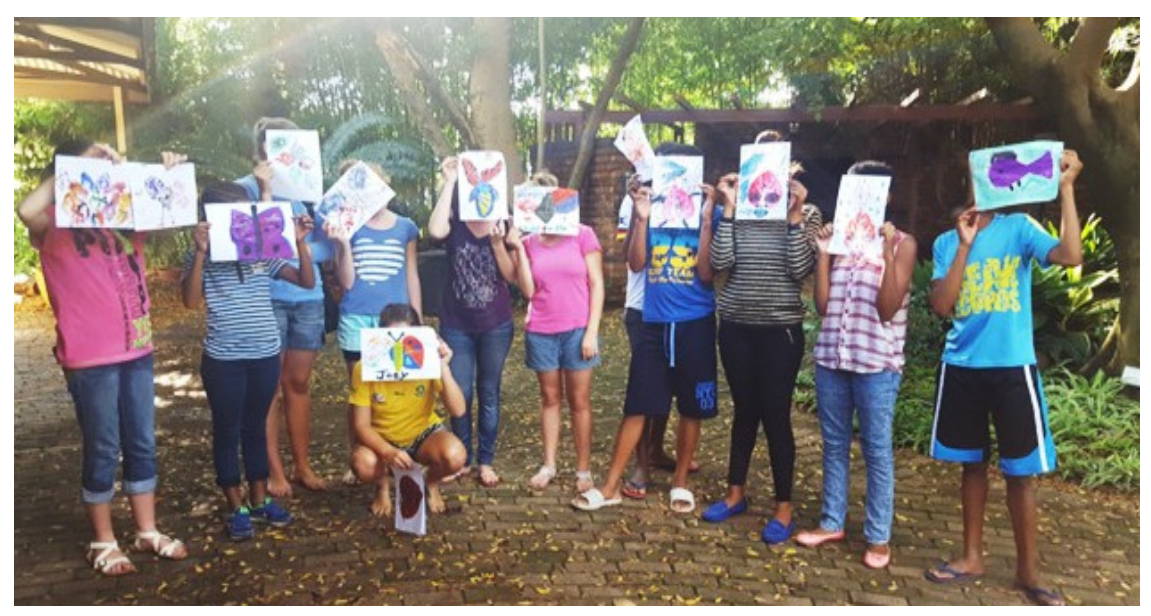




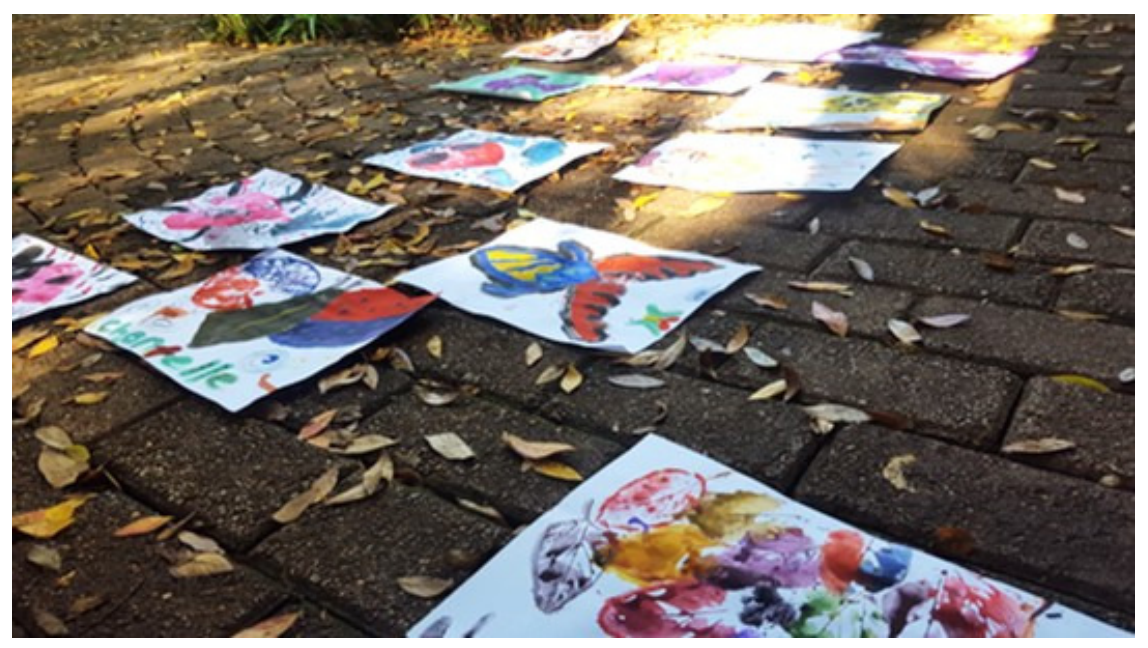

Figure 1: (SF_15): Relationship-building activity: Children experimenting with organic material during art-based exercises

Students took the lead by presenting playful and creative opportunities for the children to engage on multiple levels to enact meaningful experiences and relations. Although students directed the activities and took responsibility for the structure of each activity, they positioned themselves not as experts but relied on the lived experience and shared interests of the children (Horton \& Freire, 1990), designing activities that the children could relate to. Students took leadership by exposing the children to trans-pedagogical practices (Helguera, 2011), performing arts strategies (Boal, 2000), and team-building exercises to encourage convivial and socially engaged practices. They became sensitised to the children's differences in terms of their ages, abilities, and interests.

Moving between the groups to ensure that the activities were utilised for relationship building, I observed playful interactions as the children started to become less inhibited and more engaged. Some groups decided to conduct more intimate art-based activities — sitting in a circle on the grass (see Figure 2) or around tables, cutting out pictures, drawing, or painting while talking. Their conversations deepened from convivial group discussions to more personal one-on-one interactions. The children started to share their issues with the students. Some students found this overwhelming at first. One student regarded it as an "eye-opener" (SF_17) and was "flabbergasted" when one of the girls admitted that nothing makes her happy: "They [my parents] don't care what I say, or how I feel." The student remarked: "The emptiness and numbness in her eyes filled me with brood and distress" (SF_16). This experience taught me that students should gain affective and relational experience before entering their school milieus, in order to understand and appreciate deeply the thoughts and feelings of another. Some students began to empathise with the children's circumstances and noted that "some of the children would be in our schools that we teach one day" (SF_13). 

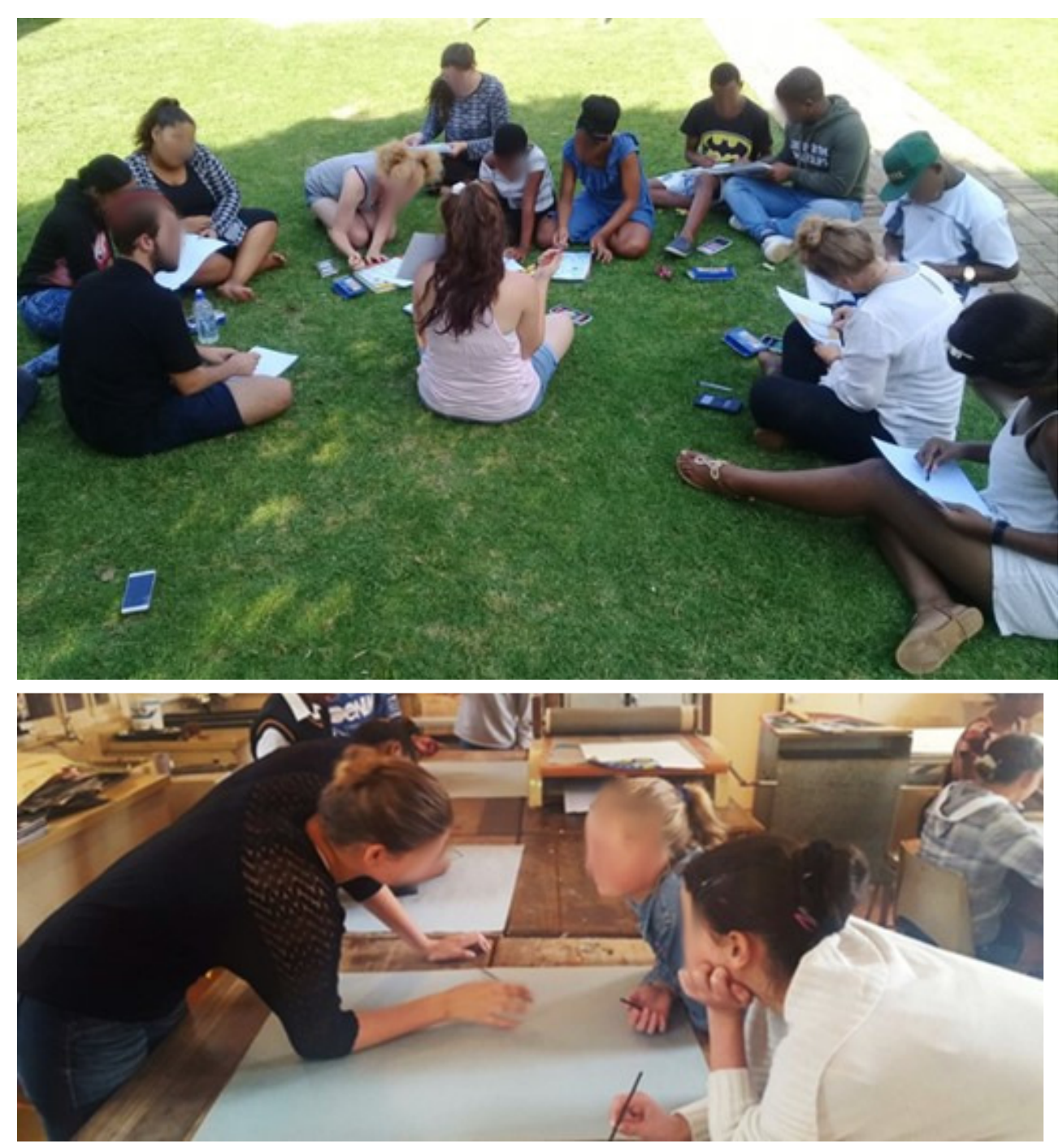

Figure 2: Relationship-building activity: Sitting in a circle talking or having a one-on-one conversation

Empathy is an essential attribute for a teacher to enable the creation of an inclusive and enabling learning environment (Killen, Richardson, \& Clark Kelly, 2010). The emotional state of a child greatly influences the way in which they learn and their attitude towards not only the subject but towards learning and the teacher (Valiente, Swanson, \& Eisenberg, 2012). Students became more sensitive about the way they communicated during the artmaking process: "As we advised we started engaging differently with the learners, being more cautious of what we say and how we say it" (SF_16). Kindness, care, and understanding became important values, "as every learner brings to the classroom their own experience, views on life and emotional baggage" (SF_3). One student, who was opposed to the CSL engagement at first, changed her views. She reconsidered her purpose for choosing teaching as a career "to initiate change," and accepted the fact that "people are fragile and that the way I speak and what I say can be harmful" (SF_3). One student suggested:

It is clear to me now . . . we are not just teachers, but we are there to give parental guidance to the learners. We have to enlighten and support them to reach their full potential. Learners come from different background, therefore need different attention and care. (SI_5) 
Leadership qualities started to emerge as students became more critical about themselves and about the way they communicate. They learnt to adapt restrictive themes to the context of the children, and engaged with multitude approaches to enact socially expressive exchanges.

\section{Theme 2: Students developed socially engaged art practices}

During the second vision-building, planning, and design session, students started "planning their projects, figure out what to do and how we are going to do it" (SI_5). The groups were required to develop a common goal that would guide them through the activities that followed. The student and children groups brainstormed their ideas and visions for their final artwork in collaborative ways to identify the environmental issues they wanted to address. Some focused on the "water crisis in the Western Cape" (SI_18), others on land art (SF_7), indigenous art (painting on rocks; SF_12), the evacuation of local oak trees in town (SI_4) or creating a kindness tree that could be decorated with their own expressive tokens of kindness hanging from the branches (SF_18).

The participatory process helped the groups to converge different ideas "to eventually get to a solution that everybody approves of" (SI_1). One group's children challenged "healthy living" and reinterpreted the topic, pointing out aspects that contribute to unhealthy living experiences, such as bullying, human trafficking, and substance abuse. The other group became micro environmental activists calling themselves "envi-tists" because they wanted, as artists, to change their school environment (SI_21). They produced functional recycled planters (SI_21; see Figure 3).
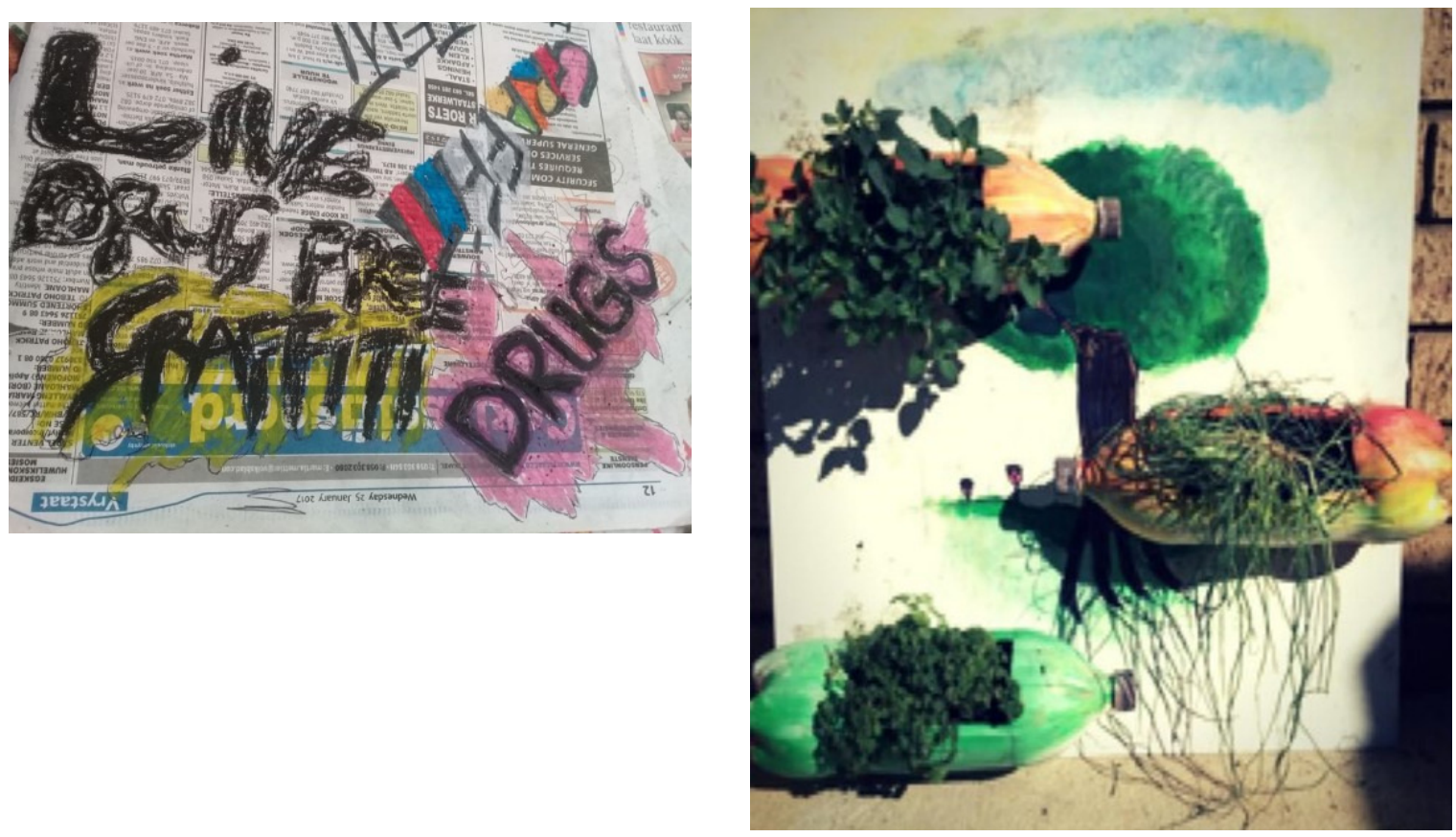

Figure 3: One group addressed social issues around the "living in a healthy environment" theme whilst the other group recreated functional objects focusing on conservation aspects

Choosing their own resource material, the students showed the children videos of environmental art (SF_8, 16, \& 18) and took them on a tour to previous community-engaged 
projects that had used recycled, emergent materials. These activities helped the groups to explain and compare the different samples and overcome conceptual barriers such as transforming their ideas into physical art products, to select appropriate materials for the artwork, and to determine the format and structure of the final work. Students began to understand that socially engaged art practices could become part of their professional teaching methods: "The most important aspect that we taught them is that art could be used to present a powerful message and address issues" (SF_10). Both CSL pedagogy and SEA theory attempt to foster a critical consciousness (Horton \& Freire, 1990) by examining various social challenges and the impact of personal action in maintaining or transforming those problems. In this case, students worked with the children to create an awareness of critical environmental issues by using an art-based platform to share ideas and discuss common goals towards visionary solutions. The children were enabled to become cocreators of new artworks that conveyed social messages. The impact of creative participation ensured that everybody added their own content to the theme and thus engaged in a "re-enactment of causes to which they personally relate" (Helguera, 2011, p. 15). The students encouraged the children to take a critical stance towards topics in order to change and transform their environments. Art liberated the children to become self-expressive.

Students thus engaged the children in various SEA forms of participation. With nominal participation, they presented artworks to the learners to observe in passive contemplation. Students also directed children to participate in completing a simple task, such as hanging kindness tokens on a cardboard tree (Helguera, 2011, p. 15). They encouraged children to participate creatively, contributing to the art work, with their choice of content such as fingerprints and natural elements to leave their mark and collectively combined the artworks in a rock garden structure. Students participated collaboratively with the children throughout the process - they shared responsibility of the ideas, content, and structure of the artwork through dialogical interaction (Helguera, 2011, pp. 14-15).

Students realised that "without cooperation the outcomes of the project will not be reached" (SF_7). Group techniques and scaffolding processes became "indispensable strategies to get closer to our end product" (SF_5). They valued working in democratic ways and agreed that through communication they could come to agreement that suited all and this came from "understanding each other equally, valuing each other's opinion and statements" (SF_8). Students noticed individual accomplishments and valued everybody's contribution: "He did fantastic work and I feel proud about how quickly he grasped the technique and the confidence he showed" (SF_6). They saw the collaborative interaction as opportunity to deepen understanding of the children and valued the role that art could play "as therapy and escapism from circumstances and immediate environments ... they opened themselves towards me and shared their dreams, emotions and aims in life" (SF_18). The usefulness of art to promote communication of "ideas and feelings, and personal, social, environmental, moral and spiritual issues through their creative activities" (SI_14) was recognised. Students affirmed my belief that art should not be reserved for the talented few only, but can be used as a tool to promote holistic outcomes: "Every single learner, regardless whether they have 
the subject art, can do art. Every learner is creative in their own manner and could, with the help of examples, create artworks and express their own creativity" (SA_6).

Students developed their professional competencies during the engagement. They shared their knowledge and skills with the children and created a stimulating learning environment, contextualising their knowledge of the CSL project theme with the social contexts of the children (Wright, 2015). Their emerging leadership qualities included working collaboratively in respectful ways (Helguera, 2011), and starting to realise the importance of addressing everybody's needs through inclusive and socially engaged art-based practices.

\section{Theme 3: Students realised the importance of collaborative practices}

In the last session, the groups participated in an exhibition event at the children's home (Figure 4), connecting their teaching to the children's world to celebrate publicly their learning accomplishments: "We celebrated because we achieved our goals, the learners reached their learning objectives and we overcame all our obstacles" (SI_1). Despite challenges such as working within limited timeframes and teaching children from diverse backgrounds, students noticed how the children became more confident towards the end, changing from "no eye contact" to being secure enough to exhibit their own work (SF_5). During the gallery walk, both student and children groups took turns to explain the social significance of their artworks.
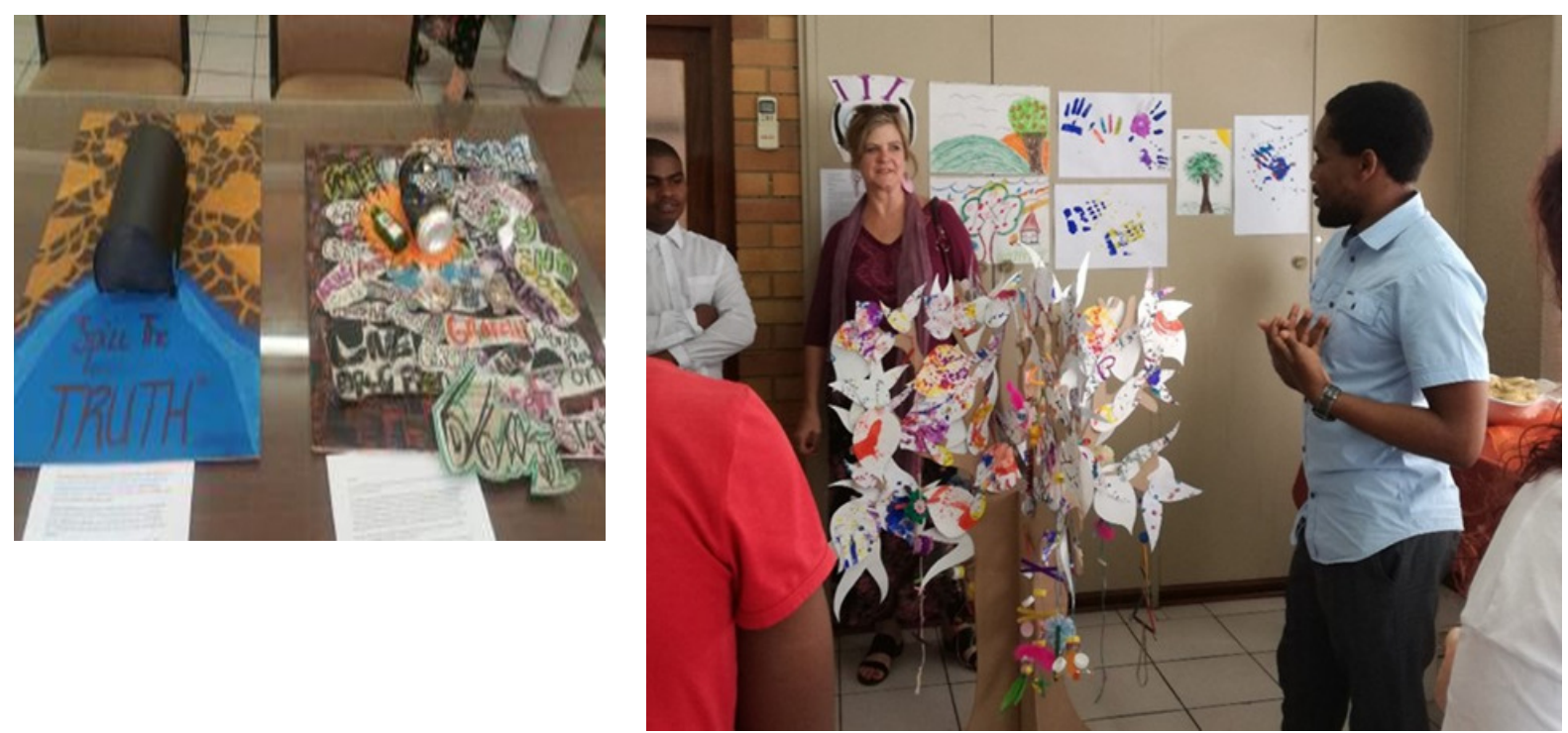

Figure 4: Celebration and exhibition session: Students and children concluded their social engagement with a gallery walk, explaining the meaning of the work. Students shared their learning experiences with the audience

Changing the conditions of their teaching practices, such as working in and outside of classrooms and connecting their art-based milieus to larger societal needs, taught students to "take hands with communities to give the children the best experience and to provoke a passion for art through partnerships with the community" (SI_20). They transformed their traditional ways of thinking: "Instead of having everything planned and predictable, we must become more resilient and consider societal needs" (SF_7). As one student stated: "Should 
my classroom not be a place where learners can break away from life's issues, a place that could inspire and console them, a safe haven . . . like nature, regardless of their backgrounds?" (SF_14)

Students transformed their understanding of diversity, they recognised the children's strengths and weaknesses and are set to teach "around these barriers" (SI_1). They realised that personal traits are part of people's diversity and that they should be more flexible and adaptable and "less critical about people's body language and expressions" (SF_7). They realised they should consider the children individually: "Everybody is unique and shouldn't be compared with the other" and therefore adjust activities to fit the children's needs instead of presenting a "one size fits all approach" (SF_4). Students learned to respect the different approaches children took: "They will not always do things how you want it to be done but rather allow them to do it to suit their understanding" (SI_1). They understood that action learning is synonymous with professional development and becoming better teachers who "never stop learning because life never stops teaching" (SI_5), and identified qualities such as tenacity, being humble, appreciative, and hard-working as professional attributes that entail "not to expect everything to fall into your lap, then you will learn . . . what it means to become part" (SF_18). Towards the end, their reflections indicated that they became more selfless, humane and caring:

I will be able to do something similar in the future . . it is not about you but absolutely about them and you need to ensure that they enjoy it. It is an unselfish action to engage with something like this. (SL_10)

The project was not only to create better future teachers but also to give back to the community by working with different children ... from different backgrounds. (SI_5)

Students engaged interactively with multi-disciplines and acquired new knowledge and skills through building relationships, working collaboratively, staying action orientated, and utilising available resources. In this way, they connected their teaching to the social realities of the children. The students transformed what they say, what they do, and how they relate to others and their circumstances (Kemmis, 2009). Although the experience made them feel unprepared initially because "no amount of theory can prepare you for the actual practice" (SF_11), they began to understand that diversity matters as the children brought unique experiences, strengths, and ideas to the project. In the last session, students developed academic posters that displayed their emergent leadership as socially engaged art teachers (see Figure 5). 

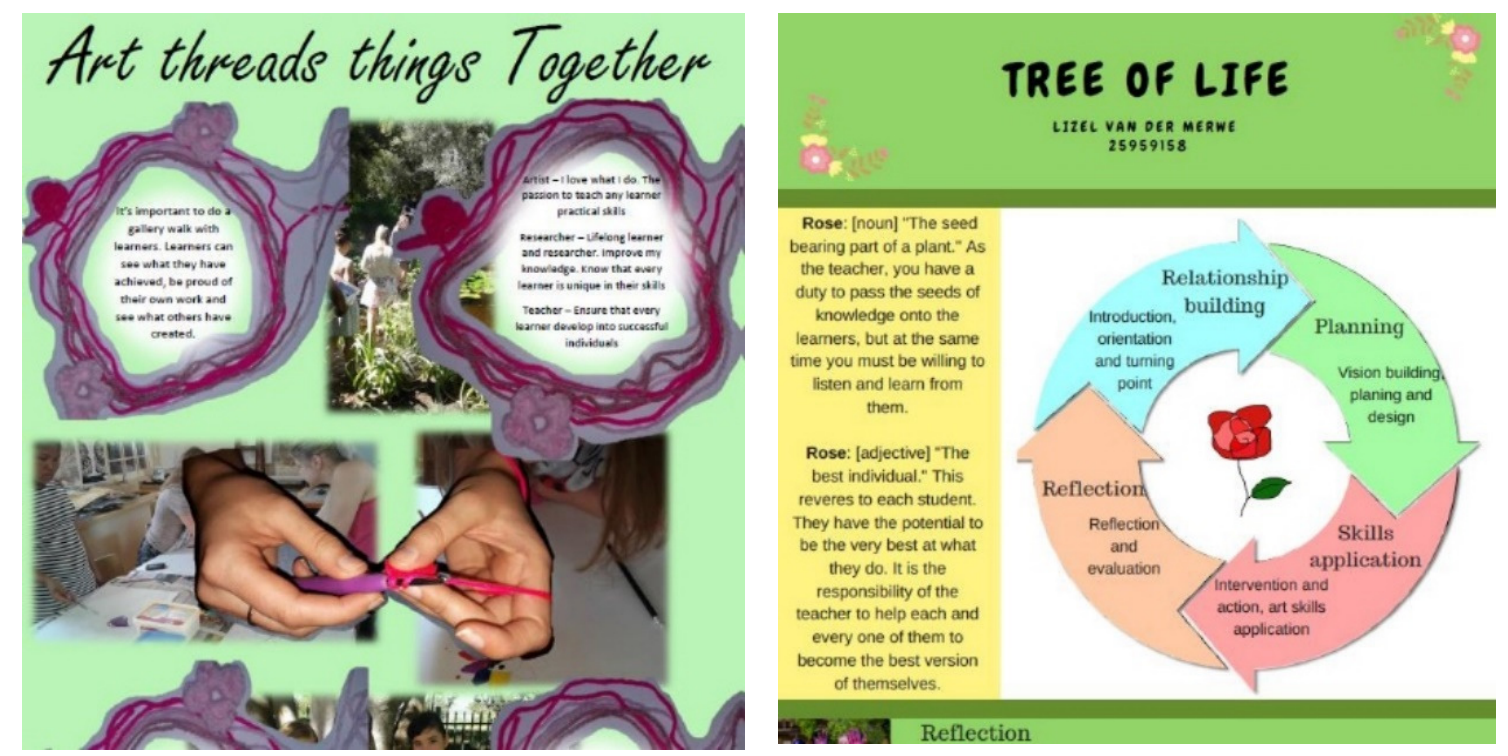

Figure 5: (SA_8 \& SF_19). Academic posters of students created in the last cycle encapsulating their learning as socially engaged teachers in art education

\section{Reflecting on my learning}

The "Living My Leadership in a Diverse and Healthy Environment" project reflects my attempt at engaging preservice art teachers in critical service-learning to demonstrate how this pedagogy could be integrated into a preservice art education programme with competing content and timeframe demands. Although these aspects seem to be constant challenges, and I recognise that CSL as pedagogy can seem like a large-scale and overwhelming undertaking for preservice teachers, students need to learn how they can use art to influence the lives of individuals - whether that be in their classrooms, schools, or broader communities (Keiser, 2005). While enduring learning was evident across students' reflections in the study, I assert that there remain areas of continued development and research to refine socially engaged CSL pedagogies within the contexts of art teacher education programming.

I have learnt three important things that I need to incorporate into my future practice. First, students need more prior exposure to critical service-learning in order to sensitise them to social issues, and to help them deal with the reaction of learners. Part of this orientation could involve examining previous projects, for example, best practices archived by institutions, or by exploring social issues that resonate with the lives of the students.

Second, students are not properly prepared to bridge the gap between theory and practice. This emerged in the reflections of the students when they had to examine suitable theories to frame their experiences. CSL preparation should include unified theories that frame diverse forms of social inclusivity, instead of introducing a multitude of theories in sub-disciplinary ways that often result in a "patchwork of learning on discrete issues" (DeLuca et al., 2011, p. 196). I therefore revised my previous model for art education (Meyer \& Wood, 2017), and added an "Introduction to CSL" learning unit to orientate students before they start with CSL. This model's cycles constitute different platforms that lead to leadership in socially engaged 
practice: knowledge, relational, creative, working, public, and professional development (see Figure 6).

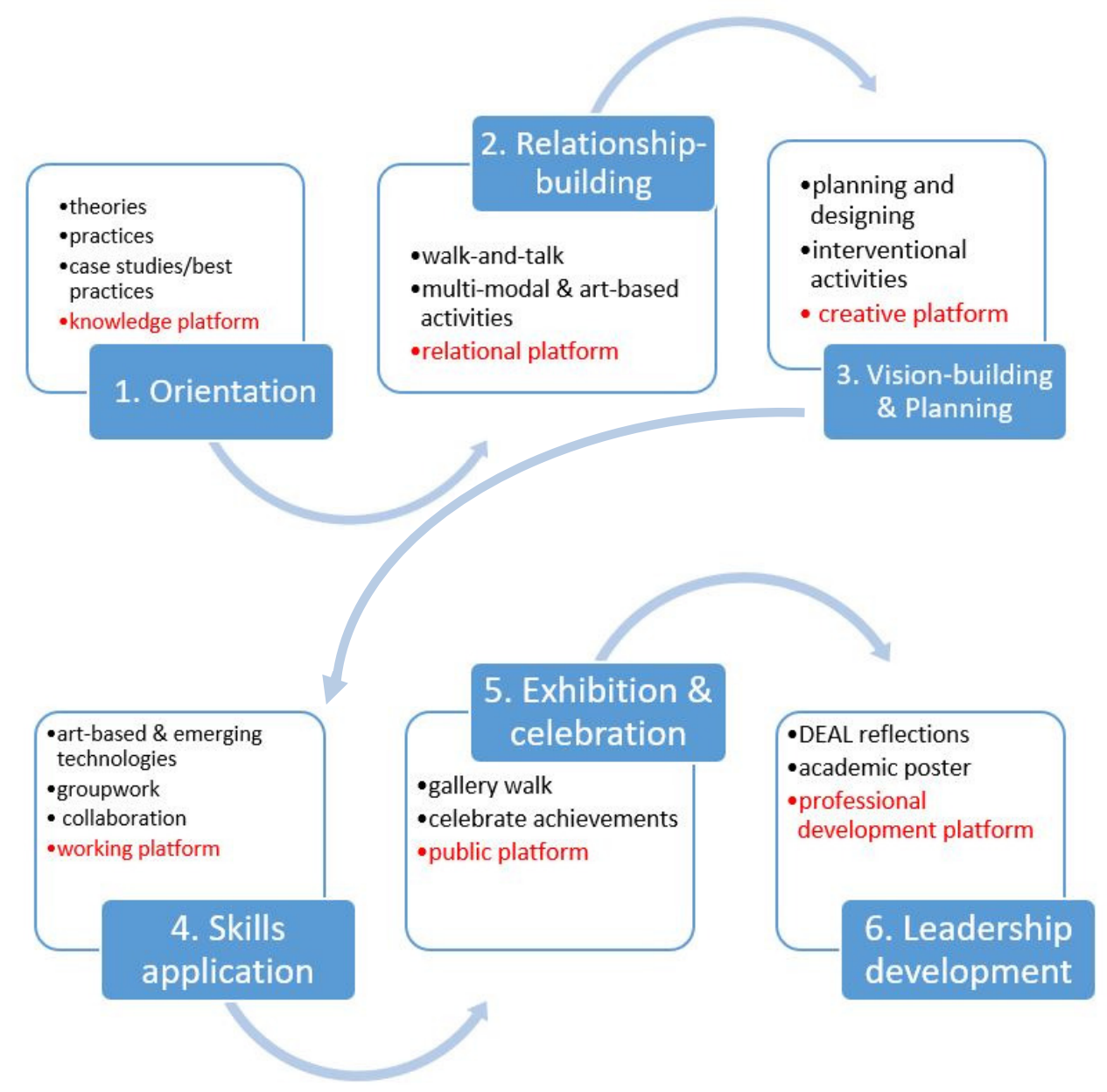

Figure 6: Model to integrate critical service-learning into art education programmes

Student reflections taught me that they would benefit from a deeper understanding of critical reflective practices and, in future, I will allocate more time to this learning process. I also adjusted the assignment instructions to make the learning expectations clearer. Although students worked in groups during the engagement process, they reflected on their own. In future, I would encourage that they also reflect on their experiences in small groups after each session to develop a "community of critical friends" (Nieto, 2000, p. 185).

\section{Conclusion}

This article has provided my explanation of how I influenced preservice art education students to become leaders in their learning environments by adopting more socially engaged practices to address my concern of art being taught in isolation from the lives and social realities of learners. I created a critical service-learning opportunity for preservice art teachers to engage with children from a nearby children's home, and guided them through the process. Analysis of their reflections supports my hypothesis that critical service-learning, together with a socially engaged art approach, contributes to preservice art teachers' professional 
development. Evidence indicated they became sensitised to learner's social realities, were able to develop strategies to improve learner engagement with social issues, and started to develop characteristics as critical, accountable, and transformational action leaders. Students examined service-learning as a new trans-pedagogical educational activity in critical ways, they took responsibility for their teaching, and constantly reflected on their practices after each session. They worked inclusively with children from marginalised backgrounds and abilities, and became intrinsically accountable not only for the success of the SEA project but also for the development of the children's creative skills, organising and designing activities most suited for the children. Their self-evaluation, evident in their changed attitudes, values, and transformational practices, indicated their professional development as leaders in art education. The model I designed explains my pedagogical interventional strategies, serves as a praxis-orientated instrument, and could guide future participatory and critical servicelearning pedagogies to increase social responsibility amongst preservice art teachers before embarking on their careers.

\section{References}

Ary, D., Jacobs, L. C., Sorensen, C., \& Walker, D. A. (2014). Introduction to research in education (9th ed.). Belmont, CA: Wadsworth Cengage Learning.

Boal, A. (2000). Theater of the oppressed. London, UK: Pluto.

Braun, V., \& Clarke, V. (2006). Using thematic analysis in psychology. Qualitative Research in Psychology, 3(2), 77-101. doi:10.1191/1478088706qp063oa

DeLuca, C., DeLagran, M. L., Feurguson, E., \& Ho, S. (2011). The equity leadership project: Preparing socially inclusive educators. In B. J. Porfilio \& H. Hickman (Eds.), Critical service-learning as revolutionary pedagogy: A project of student agency in action (pp. 179-202). Charlotte, NC: Information Age.

Department of Higher Education and Training. (2015). Revised policy on the minimum requirements for teacher education qualifications (Government Gazette, No. 38487). Retrieved from http://www.dhet.gov.za/Teacher\%20Education/National\%20Qualifications\%20Frame work\%20Act\%2067_2008\%20Revised\%20Policy\%20for\%20Teacher\%20Education $\%$ 20Quilifications.pdf

Doerr, E. (2011). Cognitive dissonance in international service-learning: Possibilities and challenges for service-learning pedagogy. In B. J. Porfilio \& H. Hickman (Eds.), Critical service-learning as revolutionary pedagogy: A project of student agency in action (pp. 71-94). Charlotte, NC: Information Age.

Ellingson, L. L. (2009). Engaging crystallization in qualitative research: An introduction. Los Angeles, CA: SAGE. 
Frith, H., \& Gleeson, K. (2004). Clothing and embodiment: Men managing body image and appearance. Psychology of Men \& Masculinity, 5(1), 40-48. doi:10.1037/15249220.5.1.40

Helguera, P. (2011). Education for socially engaged art: A materials and techniques handbook. New York, NY: Jorge Pinto Books.

Horton, M., \& Freire, P. (1990). We make the road by walking: Conversations on education and social change. Philadelphia, PA: Temple University Press.

Howard, T. C., \& Aleman, G. R. (2008). Teacher capacity for diverse learners: What do teachers need to know? In M. Cochran-Smith, S. Feiman-Nemser, \& D. J. McIntyre (Eds.), Handbook of research on teacher education: Enduring questions in changing contexts (3rd ed., pp. 157-174). New York, NY: Routledge.

Keiser, D. L. (2005). Learners not widgets: Teacher education for social justice during transformational times. In N. M. Michelli \& D. L. Keiser (Eds.), Teacher education for democracy and social justice (pp. 31-56). New York, NY: RoutledgeFalmer.

Kemmis, S. (2009). Action research as a practice-based practice. Educational Action Research, 17(3), 463-474. doi:10.1080/09650790903093284

Killen, M., Richardson, C. B., \& Clark Kelly, M. (2010). Developmental perspectives. In J. F. Dovidio, M. Hewstone, P. Glick, \& V. M. Esses (Eds.), The SAGE handbook of prejudice, stereotyping and discrimination (pp. 97-114). London, UK: SAGE.

Meyer, M., \& Wood, L. (2017). A critical reflection on the multiple roles required to facilitate mutual learning during service-learning in creative arts education. Teaching in Higher Education, 22(2), 158-177.

Mitchell, T. D. (2008). Traditional vs. critical service-learning: Engaging the literature to differentiate two models. Michigan Journal of Community Service Learning, 14(2), $50-65$.

Neururer, J., \& Rhoads, R. A. (1998). Community service: Panacea, paradox, or potentiation. Journal of College Student Development, 39(4), 321-330.

Nieto, S. (2000). Placing equity front and center: Thoughts on transforming teacher education for a new century. Journal of Teacher Education, 51(3), 180-187.

Porfilio, B. J., \& Hickman, H. (2011). Critical service-learning as revolutionary pedagogy: A project of student agency in action. Charlotte, NC: Information Age.

Rice, K., \& Pollack, S. (2000). Developing a critical pedagogy of service learning: Preparing self-reflective, culturally aware, and responsive community participants. In C. R. O'Grady (Ed.), Integrating service learning and multicultural education in colleges and universities (pp. 115-134). Mahwah, NJ: Lawrence Erlbaum. 
Rosenberger, C. (2000). Beyond empathy: Developing critical consciousness through service learning. In C. R. O'Grady (Ed.), Integrating service learning and multicultural education in colleges and universities (pp. 23-43). Mahwah, NJ: Lawrence Erlbaum.

Saldaňa, J. (2016). The coding manual for qualitative researchers (3rd ed.). Los Angeles, CA: SAGE.

The Long Walk. (2013). Walk the talk: The Long Walk education program. Retrieved from The Long Walk website http://www.htav.asn.au/sitebuilder/teachers/knowledge/asset/files/80/walkthetalkpsloa nedstewart.pdf

Valiente, C., Swanson, J., \& Eisenberg, N. (2012). Linking students' emotions and academic achievement: When and why emotions matter. Child development perspectives, 6(2), 129-135. doi:10.1111/j.1750-8606.2011.00192.x

Wood, L. (2012). "Every teacher is a researcher!”: Creating indigenous epistemologies and practices for HIV prevention through values-based action research. SAHARA-J: Journal of Social Aspects of HIV/AIDS, 9(1), S19-S27.

Wood, L., \& Meyer, M. (2016). A participatory approach to service-learning in creative arts education: A win-win learning opportunity for campus and community? Journal of Education, 65, 31-54.

Wright, D. E. (2015). Active learning: Social justice education and participatory action research. New York, NY: Routledge.

Zuber-Skerritt, O. (2011). Action leadership: Towards a participatory paradigm. Dordrecht, NL: Springer.

Zuber-Skerritt, O. (2013). How to develop lifelong action learning. In O. Zuber-Skerritt \& R. Teare (Eds.), Lifelong action learning for community development: Learning and development for a better world (pp. 29-64). Rotterdam, NL: Sense Publishers. 